\title{
CONFLICT COVERAGE BY TERROR MOVEMENTS' USE OF MASS MEDIA AND NEW MEDIA - THE CASE OF IRANI PROXIES: HAMAS, HEZBOLLAH AND THE HOUTHIS
}

Pregledni rad (Review Paper)

Received: 19 October 2021

Accepted: 22 November 2021

DOI: https://doi.org/10.37458/nstf.22.3.4

\section{Dr. Barak Bouks*}

* Dr. Barak Bouks is a Senior Research Fellow at The Europa Institute, Department of Political Studies at School of Communication \& The International BA Communication Programme, Bar-Ilan University, RamatGan, Israel. Dr Bouks specializes in Religion \& Terror he won a scholarship, to attend and present a paper, at UCSIA's Summer school, The University of Antwerp, Belgium, Under the theme "Is Faith-based Violence Religious". In 2017, he served as committee member of the Jabotinsky Prize for Literature and Research. Throughout 2017-2018, he was elected as a peer reviewer for the journals Terrorism and Political Violence, Religion State and Society \& Conflict Management and Peace Science. In 2020, he was nominated as an Editorial Team Member and the head of a consulting refereed regulation team, of the Scientific Journal "Security Science Journal", published by the Institute for National and International Security (Serbia) \& The Europa Institute (Bar-Ilan University, Israel), The Research Institute for European and American Studies - RIEAS (Greece) and ITS Institute for Transnational Studies (Germany). Main research interests are Terror \& Religion, Middle-East \& Security (Focusing in Lebanon), Arab Media (Focusing in Middle-Eastern regional media), conducting surveys, as well as qualitative \& quantitative analysis (SPSS \& Excel). In addition, Dr. Bouks serves as a commentator in the Israeli electronic media: Radio (Radio Eretz, Galei Tzahal) \& T.V Channel I24 News. 
Abstract: Hamas, Hezbollah and The Houthis are terror movements that use sophisticated means of information flow to a general public through TV, radio and New Media channels, while making use of the newest broadcasting equipment, skilled substances and target specific audiences (culminating with western countries). This study will relate through a scrutinization of these terror movements media in specific test cases, to the following hypotheses: These terror movements are guided by Iran as proxies in order to conduct pro-Iranian cognitive warfare.

The test cases had proven a use of meticulous planning in broadcasts or New-Media of Hamas, Hezbollah and The Houthis. These broadcasts or New-Media, presented a use of pre-planned targeting of specific substances to designated audiences. There is Irani involvement in the substances and coordination of Hamas, Hezbollah and The Houthis use of media and technology.

Keywords: Media, New-Media, Coverage, Terror Movements.

\section{Introduction:}

Mass media worldwide, has a significant effect on a potential audience by relaying information to a general public through TV, radio and New Media channels (culminating with Facebook, Twitter, Instagram, etc.'). They serve as devices to channel a flow of information. This article will focus on terror movements' media as Hamas \& Hezbollah and will relate also to the case of the Shiite Houthis tribe in Yemen. All of them are Iranian proxies that control a country, either de facto following a coup (Hamascontrols the Gaza strip \& the Houthis a significant part of Yemen culminating with its capital Sanaa), or by undermining the legitimate government, as Hezbollah in Lebanon. These terror movements could not operate solely without the funding and consultancy of Iran. At the beginning they implemented principles of global Arab satellite news channels as Al-Jazeera (based in Qatar) or Al-Arabia (Based in Dubai). These channels operate according to a model shaped by CNN, BBC, France 24, or Germany's DW, while broadcasting an interpretation of global affairs to the Arab audience in his native language. Al-Jazeera \& Al-Arabia proclaimed they were inaugurated in order to 
present an authentic local Arab interpretation of the news, yet, they abstain from a coverage of their home country in order not to "accidently" criticize their ruler, culminating with significant criticism of rival political countries. This was significantly clear throughout the "Arab Spring" from 2011'.

\section{Research Hypothesis:}

1. Hamas, Hezbollah and The Houthis use sophisticated means of media and new media.

2. These terror movements make use of the newest broadcasting equipment, skilled substances and target specific audiences (culminating with western countries).

3. As all of these terror movements are Irani proxies, and thus, Iran supports their means of media.

There are some techniques and substances characterizing the media of Hamas, Hezbollah and the Houthis:

\section{Posting Ultimatums.}

2. A use of live coverage (Hamas and Hezbollah implemented a coverage from Israel, through a variety of technological techniques, directly from the incident/war they covered).

1. Yeslam Al-Saggaf. "The Online Public Sphere in the Arab World: The War in Iraq on the Al Arabiya Website", Journal of Computer-Mediated Communication, 12 (1), 2006, pp. 311-334; Louay Y. Bahru. "The New Arab Media Phenomenon: Qatar's Al-Jazeera", Middle East Policy, 8 (2), June 2001, pp. 88-99. (88). Available At: http://onlinelibrary.wiley.com/doi/10.1111/14754967.00020/abstract (Downloaded: August 18, 2021); I. Galnoor. (ed.) Government Secrecy in Democracies. New-York: NY: Harper and Row, 1977; Gary C. Gambill. "Qatar's Al-Jazeera TV: The Power of Free Speech", MiddleEast Intelligence Bulletin, 2 (5), June 2000 .Available At: http://www.meforum.org/meib/articles/0006_me2.htm (Downloaded: August 18, 2021). Andrew Hammond. "Saudi Arabia's Media Empire: Keeping the Masses at Home", Arab Media \& Society, October 2007, pp. 1-11. 
3. A use of allegedly "Private" channels which are de facto related to the terror movements in order to widen the variety of covering the message.

4. Quoting the media of the "Enemy" (Hamas and Hezbollah quoted the Israeli Media).

5. Some operate international languages websites: English, French, German, Spanish, etc.'.

6. A use of advanced equipment (satellite or internet), applying the newest methods of new media and maintaining pages in several European languages. This requires techniques, budget, and an expertise in foreign languages. As we relate to local terror movements, they require an assistance which may be related to their sponsor- Iran!

Case No. 1: Hamas' Coverage of "Operation Guardian of the Walls", May $10^{\text {th }}, 2021$

Hamas has a "Governmental" TV channel, "Al-Aqsa". On May $10^{\text {th }}, 2021$, it had launched a special live coverage of riots which were erupted in the Temple Mount. They nominated a spokesperson for a "Unified Room" of Hamas and PIJ (Palestinian Islamic Jihad) to give a series of ultimatums to Israel.

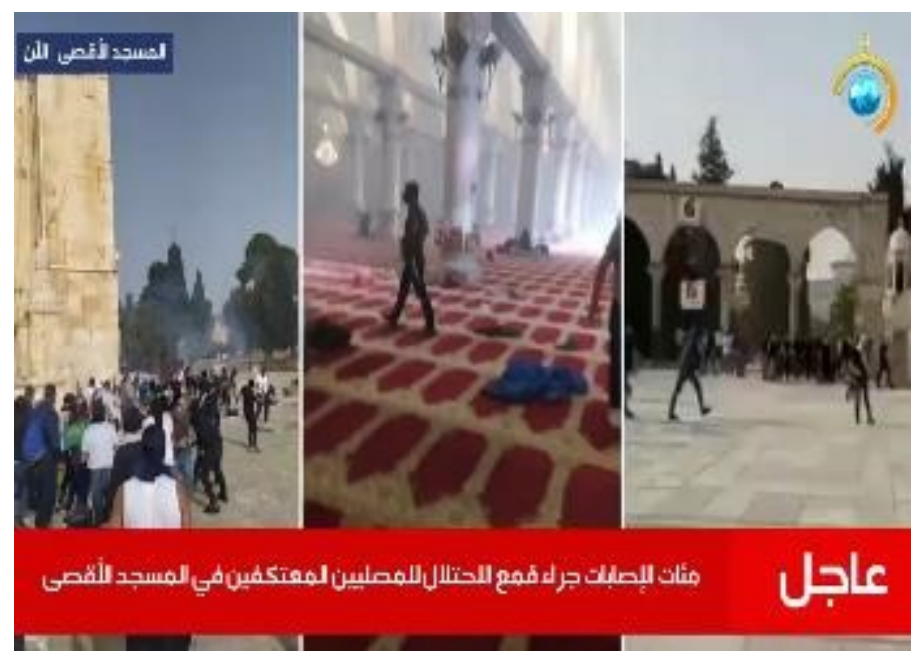


As the initial one was a vouge proclamation made by Hamas on May 10th, according to which Israel was given a few hours to pool out its security forces that day from Jerusalem, "Or else"...
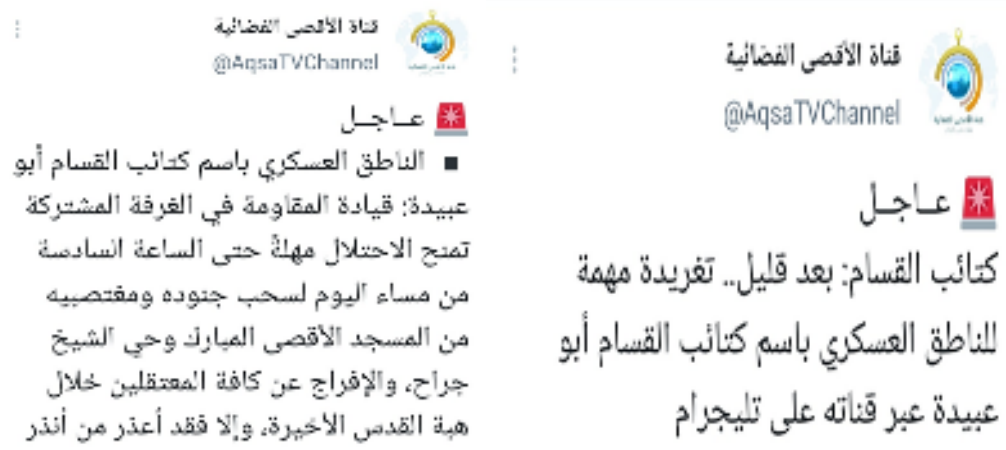

Hamas launched a massive rocket attack on Israel from May 10th, in the evening. Its TV channel had posted news bulletins in their TV broadcasts and twitted online reports of sirens in major Israeli cities, e.g., an alarm in Tel-Aviv.

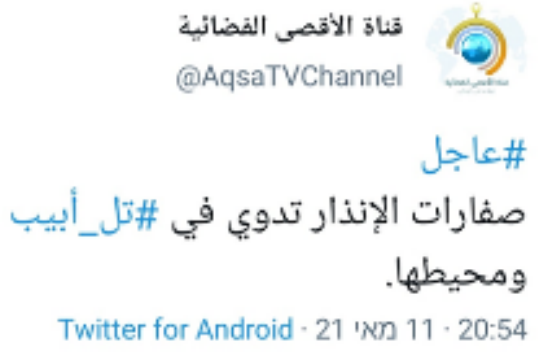

21 ציוצים מחדש 5 ציוצי ציטוט 86 סימונים כאהוב

Towards the early hours of May 12th (5:00 AM), Hamas posted the headline page of an Israeli Newspaper "Maarive" as the movement translated the title "The Country is Burning". This is a plane use of the "Enemy's" media in order to brand a victory as "The enemy admits his current status- Not me". Hamas also used "An independent" private website "Gaza Now". The website posted in his twitter page, a collage of 20 cities and villages inside Israel, as Jaffa (Next to Tel-Aviv), under the title "Historic Palestine". As no one cannot operate freely under Hamas' rule, 
this is another mean to relay a message through a "Non-Formal" media device ${ }^{2}$.

The "Collage" of "Historic Palestine" which is Israel itself culminating with Tel-Aviv-Jaffe

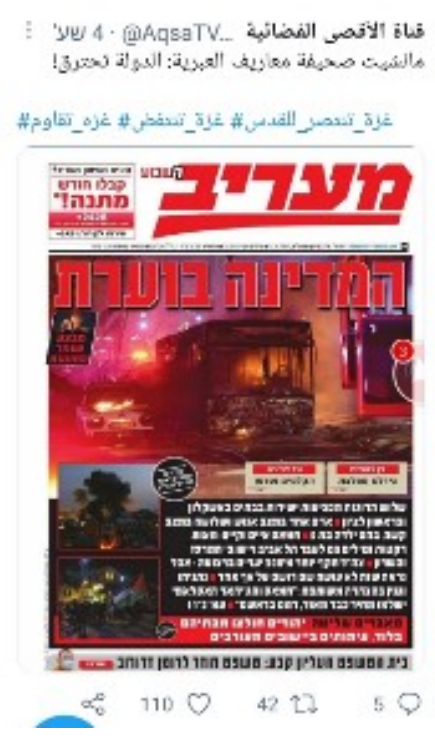

Gaza Now - الأن @GNNANOW

تملسطين الناريخية

Hamas' TV's twit of "Our Country is Burning”

Case No. 2: Hezbollah's' Coverage of Operation "Northern Shield", December $4^{\text {th }}, 2021$

In this case I will relate to a formal channel of Hezbollah "AlManar" and a private Hezbollah affiliated channel "AlMayadeen". On December 4th, 2021, Israel discovered some unused tunnels of Hezbollah in the Israeli-Lebanese border. Both channels ignored Israeli media reports by continuing with regular programs.

2. Al-Aqsa TV's Twitter Page; Barak Bouks. "Lessons from Hamas' Media Strategy and its Effect on Israeli Civilians", The Times of Israel. Last Modified June 7, 2021. Available At: https://blogs.timesofisrael.com/lessons-fromhamas-media-strategy-and-its-effect-on-israeli-civilians/ (Downloaded: August 18, 2021); Gaza Now Twitter Page. 
“Al-Mayadeen" Channel

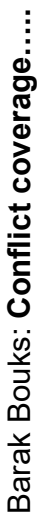

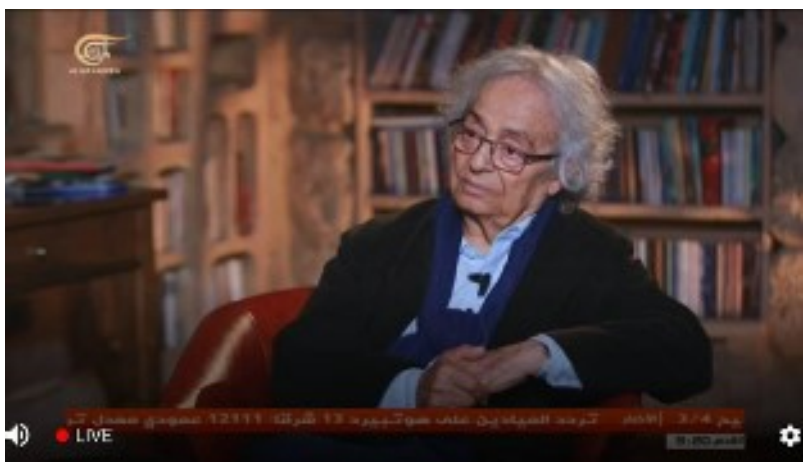

"Al-Manar" Channel

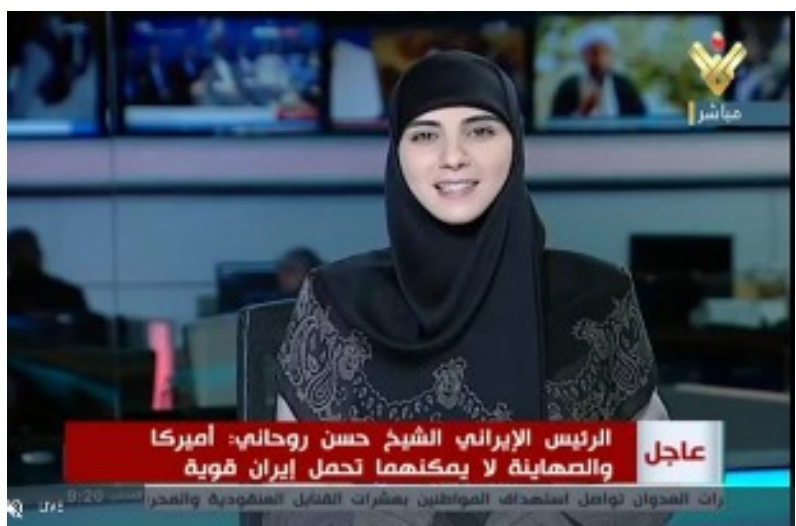

As the event continued "Al-Mayadeen" channel began a live coverage from the border. At the beginning via telephone, and later on by a live coverage.

\section{"Al-Mayadeen" Channel}

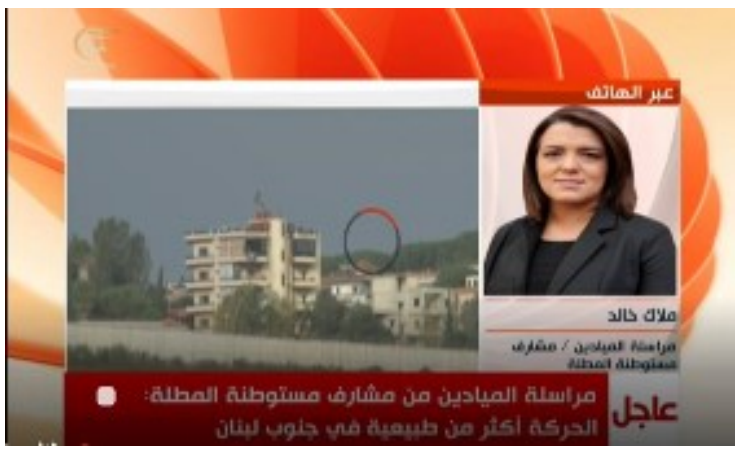


"Al-Manar" channel began reporting via telephone only a few hours following "Al-Mayadeen" channel (as the latter already reported live from the area).

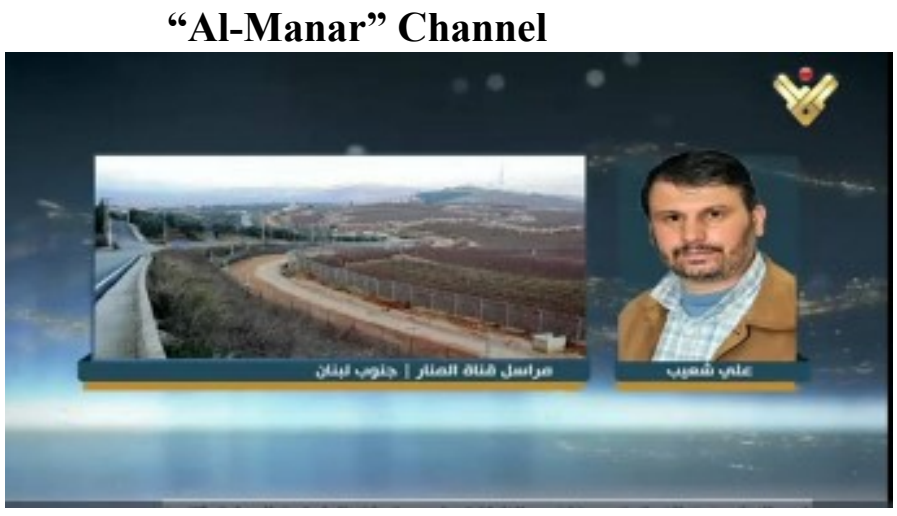

Hezbollah's channel has all the means for an immediate direct coverage as is demonstrated other cases: On September 1st, 2019 (The first day of school in Israel), Hezbollah fired an antitank missile towards an IDF vehicle in Avivim, close to the Lebanese border (not far from the former incursion we discussed).

\section{"Al-Manar" Channel}

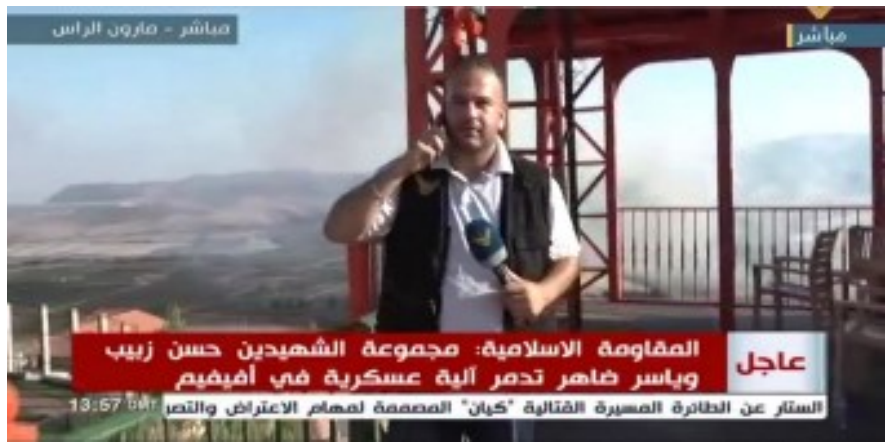

Hezbollah reported the event as a live coverage from a post in "Maroun A Ras" (We can notice the reporter in the Enclosed picture which was retrieved from their channel). Usually "AlManar" channel has the capabilities to present a live and efficient coverage of equivalent events as in events as of a sniper fire of 
Hezbollah from August 26th, 2020 around midnight, at an Israeli post close to the Lebanese border.

Enclosed is a "Special" live coverage of Hezbollah TV "AlManar" at 00:40, Noting IDF had fired an array of fire lights in the area of the village "Mis-AL-Jabal".

\section{"Al-Manar" Channel}

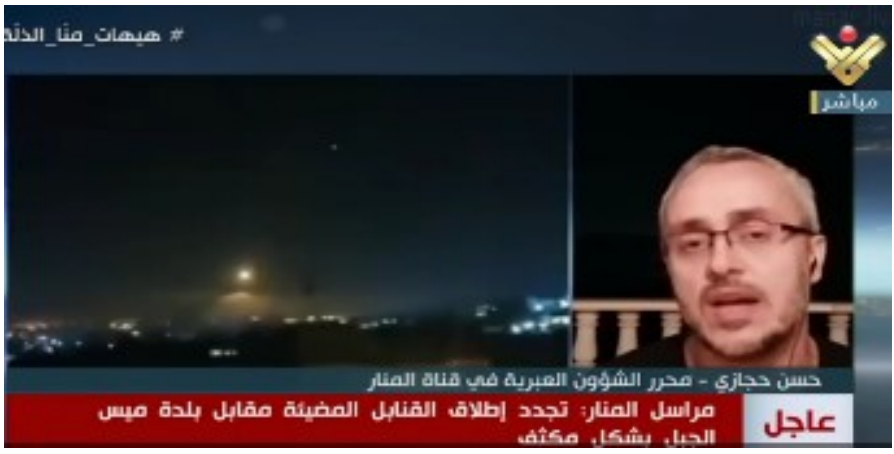

The following day Hezbollah presented a video clip, which portrayed the event and mapped an Israeli post nearby (See the enclosed frames which were retrieved from this clip). This proves how Hezbollah scrutinizes meticulously the Israeli border, albeit agreement 1701 from the end of the 2 nd Lebanese war, prohibiting the presence of this terror movement near Israel!

\section{"Al-Manar" Channel}

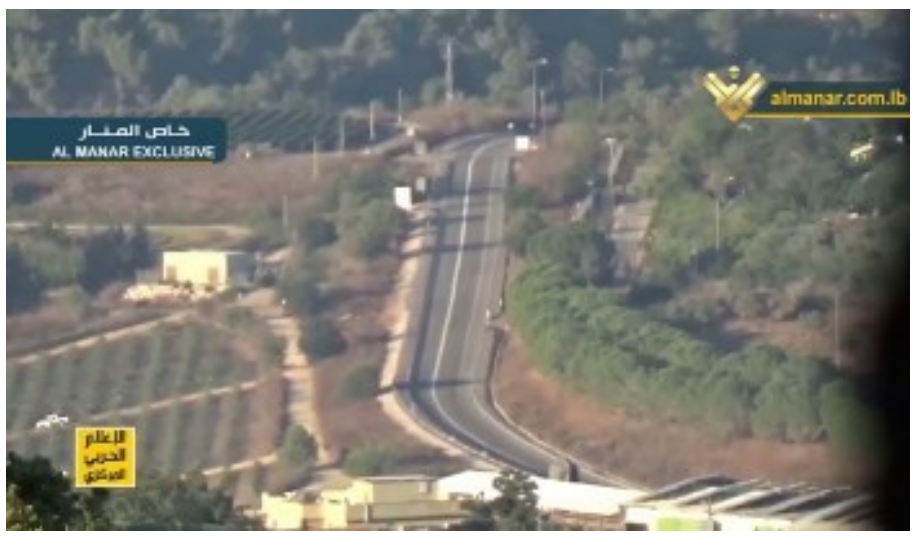




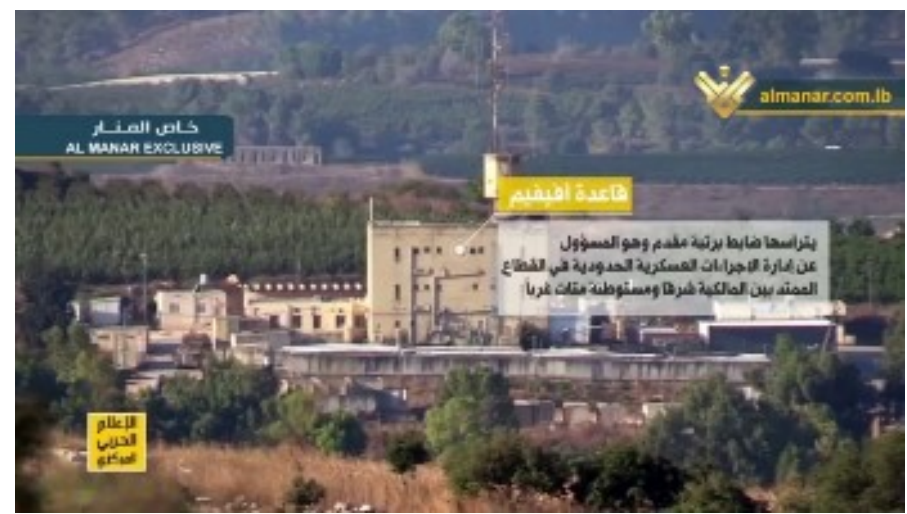

These coverage techniques, as a use of high-tech equipment, an array of reporters near the Israeli border and a coherent surveillance, demonstrate the implementation of a warfare doctrine of the sponsor- Iran! The use of an informal TV for relaying Hezbollah's propaganda by informal affiliates of the terror movement, provided Hezbollah some time for arriving at a decision or possibly receiving instructions from Iran on how to acknowledge the Israeli discovery of the tunnels ${ }^{3}$.

Case No. 3: The Houthis in Yemen: The Formal Yemenite News Agency Saba-Net- November $13^{\text {th }}, 2017$

As the Houthi rebels controlled the capital Sanaa, the governmental news agency Saba-Net, became their voice to the world. On November 13th, 2017, following a ballistic missile launch to the Saudi capital Riad (An international airport), and in addition, toppling a military helicopter patrolling the border, on which there were high ranking officials of the Saudi army culminating with a crown prince, the Saudi coalition retaliated.

Saba-Net agency used the terminology of an attack by "Mercenaries", in order to describe a Saudi backed by US 
coalition attack on the cities of Tais and Marib in Yemen, which were defended by "popular forces".

We can notice that the agency presents an opposite framed report. In this manner, the US- Saudi coalition against a terror movement is defined as "US-Saudi Aggression", while reports of casualties by the Houthis are portrayed as victims.

\section{The Formal Yemenite News Agency Saba-Net}

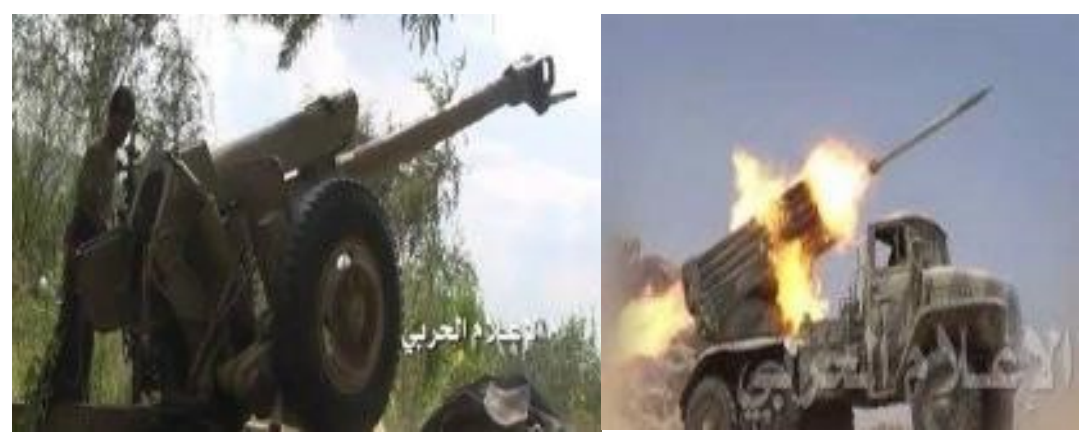

On December 4th, 2017, the former Yemenite president AliAbdullah Saleh, was assassinated by the Houthis albeit being their former ally, when he tried to escape from Sanaa. The Houthis assassinated him due to his support of the Saudi coalition. Following the assassination, Hezbollah's channel in Lebanon "Al-Manar", reported the assassination (although it was not related to Lebanon).

The footage Hezbollah presented was of a close-up video clip of the assassination, which was recorded from a cellphone. There were also commentators in the studio. One has to note that equivalently to Hezbollah's channel that operates from Beirut in Lebanon, the Houthis operate their own channel from this city, designated for Yemen. Both of these channels are pro-Iranian ${ }^{4}$.

4 Saba-Net Agency. Available At: https://www.sabanews.net/en/ (Downloaded: August 21, 2021). 


\section{Conclusions:}

1. The test cases had proven a use of highly advanced equipment, messages, and a use of meticulous planning in broadcasts or New-Media of Hamas, Hezbollah and The Houthis. We can also add that Hamas also uses sophisticated technology to launch Cyber attacks as in using fake Facebook profiles of women, "Honey Traps", designated for the Israeli audience, by using a program that can control some cellular utilities as Camera, GPS, Contacts \& Files. Following the installation of this program, it sends the information back to Hamas' headquarters. This technology also proves an intervention by a sponsor who provides the equipment and the skills to maintain such an operation.

2. These broadcasts or New-Media, presented a use of preplanned targeting of specific substances to designated audiences.

3. We had proven Irani involvement in the substances and coordination of Hamas, Hezbollah and The Houthis use of media and technology.

\section{BIBLIOGRAPHY:}

Al-Aqsa TV's Twitter Page.

Al-Manar TV.

Al-Mayadeen TV.

\section{REFERENCES}

1. Al-Saggaf, Yeslam. "The Online Public Sphere in the Arab World: The War in Iraq on the Al Arabiya Website", Journal of Computer-Mediated Communication, 12 (1), 2006, 311-334. 
2. Bahru Louay Y. "The New Arab Media Phenomenon: Qatar's AlJazeera", Middle East Policy, 8 (2), June 2001, 88-99. (88). Available At:

3. http://onlinelibrary.wiley.com/doi/10.1111/14754967.00020/abstract (Downloaded: August 18, 2021).

4. Bouks, Barak. "Lessons from Hamas' Media Strategy and its Effect on Israeli Civilians", The Times of Israel. Last Modified June 2021.2 Available https://blogs.timesofisrael.com/lessons-from-hamas-mediastrategy-and-its-effect-on-israeli-civilians/ (Downloaded: August 18, 2021).

5. Galnoor. I. (ed.) Government Secrecy in Democracies. NewYork: NY: Harper and Row, 1977.

6. Gambill, Gary C. "Qatar's Al-Jazeera TV: The Power of Free Speech", Middle-East Intelligence Bulletin, 2 (5), June 2000.

7. Available At: http://www.meforum.org/meib/articles/0006_me2.htm (Downloaded: August 18, 2021).

8. Gaza Now Twitter Page.

9. Hammond, Andrew. "Saudi Arabia's Media Empire: Keeping the Masses at Home", Arab Media \& Society, October 2007, 1-11.

10. Saba-Net Agency. Available At: https://www.sabanews.net/en/ (Downloaded: August 21, 2021). 